\title{
True Relations
}




\title{
A true
}

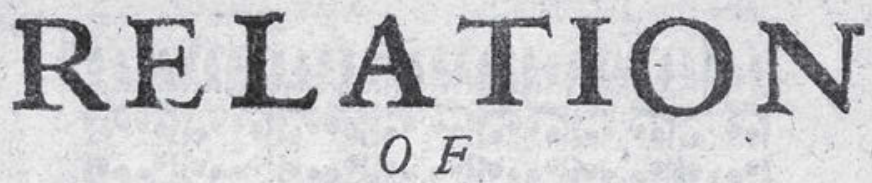

The late great Mutiny which was in the City and County of NoRwich, April 24.1648.

\author{
W I T H
}

That accident that befell thofe Mutiniers that day:

there being as is thought, above 200 . flaine by the fireing of 98 .

Barrels if Powder;being truly related in s Letcer from the Gity of Norwich, to an honourable Perfor of the honourable Houfe of Comnions, with the Vutes of she Houfe concerning the fame, and ordered to be printed, to prevent mifinformation.

In fove $m$ quans foderuxt $\& \mathrm{c}$.

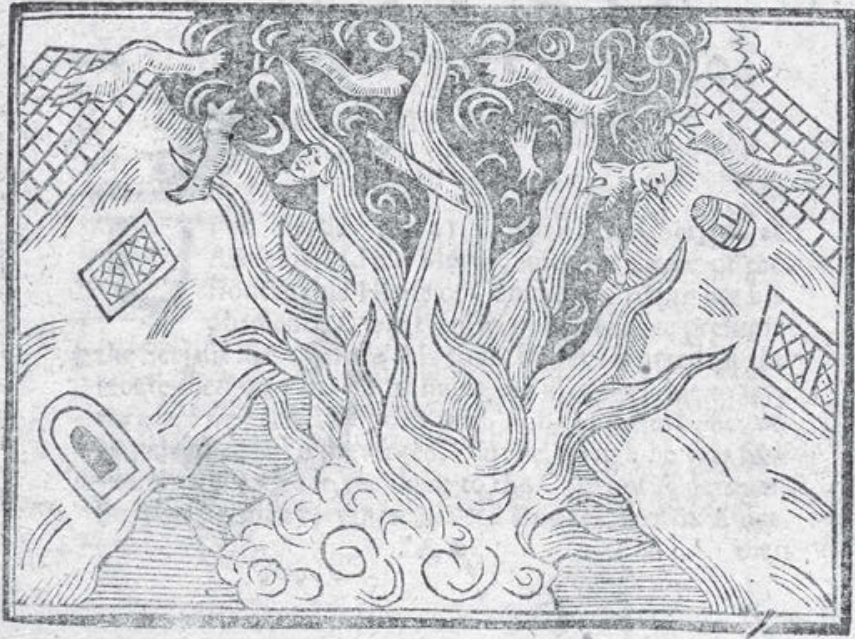

LONDON. Prinied for George Whitcington, 1643. 


\section{TRUE}

\section{RELATIONS}

Reading, Literature, and Evidence in Seventeenth-Century England

FRANCES E. DOLAN

\section{$\overline{\text { PENN }}$}

UNIVERSITY OF PENNSYLVANIA PRESS 
Copyright (C) 2013 University of Pennsylvania Press

All rights reserved. Except for brief quotations used for purposes of review or scholarly citation, none of this book may be reproduced in any form by any means without written permission from the publisher.

\author{
Published by \\ University of Pennsylvania Press \\ Philadelphia, Pennsylvania I9IO4-4II2 \\ www.upenn.edu/pennpress
}

Printed in the United States of America on acid-free paper IO 987765432 I

Library of Congress Cataloging-in-Publication Data

Dolan, Frances E. (Frances Elizxabeth), I960-

True relations : reading, literature, and evidence in seventeenth-century England / Frances E. Dolan. — Ist ed.

p. $\mathrm{cm}$.

Includes bibliographic references and index

ISBN 978-0-8I22-4485-4 (hardcover : alk. paper)

I. English literature-Early modern, I500-1700-

Criticism, textual. 2. Law and literature-EnglandHistory-I7th century. 3. Evidence-History-I7th century. 4. Knowledge, Theory of, in literature. 5. Reality in literature. 6. Truth in literature. 7. EnglandIntellectual life- - ith century. I. Title.

$\mathrm{PR}_{438.42} 2 \mathrm{OI} 3$

$2 \mathrm{OI} 2 \mathrm{O} 3 \mathrm{I} 342$

Frontispiece. Title page of $A$ True Relation of an explosion. The attempt to "prevent misinformation" is typical of texts that present themselves as true relations.

The flying body parts of the mutineers might stand for the fragmentary, dynamic nature of evidence, and the demand it places on readers to collect and relate scattered remains. Reproduced by permission of The Huntington Library, San Marino, California. 